\title{
UKRAINIAN AGRARIANISM OF THE PERIOD \\ OF THE UKRAINIAN REVOLUTION OF 1917-1921 \\ IN INTELLECTUAL HERITAGE OF G. SIMANTSIV
}

\section{Kornovenko S. V.}

\section{INTRODUCTION}

One of the results of the Ukrainian Revolution of 1917-1921 was the mass emigration of those who disagreed with the Soviet model of statehood. Ukrainian emigrants were dominated by representatives of intellectual and creative activity, public and political figures, the military and others - those who did not accept Soviet Ukraine. Interwar Europe became a refuge for such Ukrainians. The largest Ukrainian emigrant circles were concentrated in Poland, Czechoslovakia, and Romania. The fate of Ukrainian emigrants was different, it was largely determined by the country's domestic policy towards emigrants, their personal nature.

In the latest historiographical tradition, various issues on the history of Ukrainian emigration in the countries of Central-Eastern Europe of the interwar period are in the field of scientific attention. Researchers have elucidated the socio-cultural aspects of Ukrainian emigration to Czechoslovakia in the $1920 \mathrm{~s}^{1}$, the activities of Ukrainian political emigration in European countries in the $1920 \mathrm{~s}^{2}$; the number and social structure of Ukrainian emigration in European countries in the interwar period ${ }^{3}$; activity of Ukrainian emigration in European countries in the interwar period of the twentieth century ${ }^{4}$; composition, structure, socio-political practices of Ukrainian political emigration in Poland on the territory of Volyn Voivodeship ${ }^{5}$; establishment and activity of the Ukrainian Academy of

\footnotetext{
1 Даниленко O. Українська еміграція в Чехословаччині. URL: https:// etnic.history.univ.kiev.ua/data/2001/10/articles/6.pdfx.

2 Плазова Т. Українська політична еміграція у першій половині 20-х років ХХ ст. Українська національна ідея: реалї та перспективи розвитку. 2008. Вип. 20. C. $118-121$.

${ }^{3}$ Плазова Т. Українська еміграція в країнах Європи в міжвоєнний період XX ст. Науковий вісник ЛНУВМБТ імені С.Г. Гжицького. 2010. Т. 12. № 2 (44). Ч. 5. С. 225-229.

${ }^{4}$ Плазова Т. Діяльність української еміграції в країнах Європи у міжвоєнний період XX ст. URL: https://ena.lp.edu.ua

5 Давидюк Р. Українська політична еміграція в Польщі: склад, структура, громадсько-політичні практики на території Волинського воєводства : дис... док. іст. н. Львів, 2017. 704 с.
} 
Economics in Czechoslovakia in $1922-1935^{6}$; artistic, cultural and social life of the Ukrainian emigration in interwar Czechoslovakia ${ }^{7}$, etc.

At the same time, in our opinion, it is important to study the intellectual Ukrainian product in exile. First of all, the further theoretical development of such a European peasant-centric phenomenon of the second half of the nineteenth century - 1930s, as agrarianism, represented, in particular, by Ukrainian agrarianism. In this context, it is scientifically sound to turn to the intellectual heritage of G. Simantsiv. It is about his speech "The Newest Agrarianism", delivered in the Ukrainian Academic Community in Podebrady and in the Republican-Democratic Club in Prague in 1929.

The author of the article aims to explore the intellectual heritage of G. Simantsiv, presented in his report "The Newest Agrarianism", to reveal the content of Ukrainian agrarianism of the interwar period.

\section{The essence of agrarianism}

Compositionally, the speech consists of three parts: sociological foundations; socio-political system; results. They set out the author's understanding of modern Ukrainian agrarianism, its content and essence, the characteristic features that distinguish it from other socio-political ideologies and practices.

In the 1920's and 1930's in such European countries as Poland, Czechoslovakia, Romania, Bulgaria, etc., a common peasant-centric phenomenon, the state doctrine was agrarianism. He was represented by political parties and organizations, government circles. The ideas of agrarianism were the basis of agrarian reforms in these countries, their social basis was the peasantry - the largest number of agro-industrial countries in Central and South-Eastern Europe. At the same time, the ideas of socialism were no less popular in the socio-political life of Europe at that time. Between agrarianism and socialism, their theorists and supporters, there was competition, discussion, and so on. G. Simantsiv as a representative of Ukrainian agrarianism reasonably argued the separation of agrarianism from socialism. He emphasized that agrarianism and socialism were different political phenomena, as were the peasantry and the working class, which were the social basis of agrarianism and socialism, respectively ${ }^{8}$. In the

${ }^{6}$ Уткін О. Вища аграрна школа української еміграції (1922-1935 рр.). Київські історичні студї. 2018. № 1 (6). С. 94-102.

7 Пеленська О. Україна поза Україною: Енциклопедичний словник мистецького, культурного і громадського життя в міжвоєнній Чехословаччині (1919-1939). Прага, 2019. $331 \mathrm{c}$.

8 Центральний державний архів вищих органів влади і управління України (далі - ЦДАВОВУ), Ф. 4465, Оп. 1, Спр. 747, Арк. 37, Арк. 2. 
discourse proposed by G. Simantsiv we observe the longevity of the Ukrainian agrarian tradition, initiated by P. Kulish, which found a logical continuation in the agrarian ideas of M. Hrushevsky, P. Skoropadsky, V. Lypynsky, program provisions of some national political parties during the Ukrainian Revolution 1917-1921 years, regarding the separation of the city from the countryside.

At the same time, if the predecessors - P. Kulish, P. Struve emphasized the open antagonism between city and countryside, G. Simantsiv offers a different approach. He appeals to the historical experience, especially the Soviet one, and notes: “... Socialism, after the failed practice of Russian Bolshevism... seeks in the peasantry a partner for itself rather than actively fighting it. Equally for the peasantry, workers' socialism is the most natural ally on the path to progress" of "The Newest Agrarianism", emphasizing the separation of agrarianism from socialism, sees no reason to oppose them. Considers peasants and workers allies in development. At the same time, the thinker clearly defines that along with socialism, "a new sociological force has grown: agrarianism" $"$.

We are impressed by such judgments. In fact, during the second half of the nineteenth century - in the 1930's in Europe, in Ukraine, a qualitatively different peasant was formed. He became a peasant-ideoman - an active subject of history, the bearer of agrarian ideology. The fundamental difference between the peasantry and the working class in everyday life, culture, worldview, etc. has formed some separate ideological meanings of agrarianism and agriculture. socialism.

G. Simantsiv, operating on the achievements of the classics of European agrarian thought, such as M. Hodza, argued that the difference between agrarianism and socialism is that "socialism for a long time did not take into account the peasantry as a social factor", it "was listed with only two human

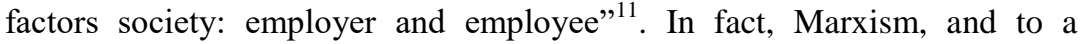
greater extent Bolshevism, leveled the role of the peasantry. According to the imperial tradition, the Bolsheviks considered him an inert, promonarchist force, an antagonist of the proletariat, expressing the interests of which they positioned themselves. They ignored the socio-cultural changes that took place among the peasantry, in particular the Ukrainian, during the second half of the nineteenth - early twentieth century. The Bolsheviks

\footnotetext{
${ }^{9}$ ЦДАВОВУ, Ф. 4465, Оп. 1, Спр. 747, Арк. 37, Арк. 2.

${ }^{10}$ Ibid

${ }^{11}$ Ibid. Арк. 3.
} 
adopted the idea of peasant inferiority ${ }^{12,13}$. They developed the concept of the peasantry as an ally of the proletariat in the struggle for a bright future. However, the proletariat was proclaimed the hegemon, which allegedly had nothing to lose but its own shackles ${ }^{14}$. Instead, the peasant was seen as a subject with a "dual psychology".

In this way, only actors such as the bourgeoisie and the proletariat were active in Marxist/socialist/Bolshevik doctrine. An active subject such as the "grain-grower", different from the "employer" and the "employee", was overlooked. Its distinctiveness, according to G. Simantsiv, is that the farmer is not a bourgeois or a proletarian, he is "a new type of social production; ... The bearer of individualism, because he is both an entrepreneur and a producer, and equally comes as a fellow citizen, in which both factors the employer and the entrepreneur - in one person"15.

This feature of the peasant, according to the thinker, determines the separation of agrarianism as a representative of peasant ideology from socialism - a representative of workers' ideology. According to the author of "The Newest Agrarianism", agrarianism "reflects in itself" "this peasant psychology and this peasant philosophy"16. For peasants, the advantage of agrarianism as a peasant ideology among other socio-political analogues, rightly believes G. Simantsiv, is that 1) it does not invent anything new, is natural for the peasantry; 2) "it does not build abstract schemes, detached from life"; 3) avoids utopian goals and objectives; 4) is a systematized "spiritual treasures of the peasantry,... seeks to be... an expression of peasant interests, 5) "organizer of peasant social activity"; 6) is closely and directly connected with the peasant socio-political self-awareness"17.

It is noteworthy that in substantiating his position G. Simantsiv takes into account the work of not only the classics of European agrarianism, but also Ukrainian socio-political thought, represented by the views of V. Lypynsky. For example, like the latter, the author of "The Newest Agrarianism", uses such a concept as "grain-grower". He uses it as a synonym for the peasantry. In his judgments, the thinker appeals to such a general agrarian category as "laws of the land". It is about the struggle of two opposites: the "law of land" and the "law of capital", that the classic of Ukrainian conservatism has repeatedly written. In particular, V. Lypynsky, in accordance with the

\footnotetext{
12 Ленин В. Полное собрание сочинений. Москва, 1979. Т. 12. С. 362-366.

13 Ленин В. Полное собрание сочинений. Москва, 1976. Т. 16. С. 235, 313, 325-326.

${ }^{14}$ Сафонов Д. Крестьянство как объект и субъект процесса модернизации. Вісник Черкаського університету. Серія історичні науки. 2012. № 35 (248). С. 15-18.

${ }^{15}$ ЦДАВОВУ, Ф. 4465, Оп. 1, Спр. 747, Арк. 37, Арк. 3.

${ }^{16}$ Ibid.

${ }^{17}$ Ibid. Арк. 7.
} 
general principles of Eastern European agrarianism, clearly distinguished two worlds: the world of countryside and land and the world of city and capital. V. Lypynsky considered psychology to be the basis for distinguishing these worlds. He is convinced that the psychology of the farmer and the psychology of "stock exchange gesheftsmakers" are two opposites that do not intersect, even at an imaginary point. Their psychologies are fundamentally different in responsibility and values ${ }^{18}$. In V. Lypynsky's interpretation, the "struggle not for life but for death" continues between them. He calls these worlds "laws": "the laws of the earth and the laws of capital. The old civil law, based on the possession of land, and the new commercial law, based on the possession of capital ${ }^{19}$. This is a struggle, the classic of Ukrainian conservatism reasoned, a struggle between two irreconcilable worldviews. The fundamental difference between them, in our opinion, is a socio-cultural abyss caused by ways of life, values, and the meaning of life. At its core, this struggle is "a deadly battle between the countryside and the modern capitalist world. The state-economy and the state-exchange" $" 20$.

G. Simantsiv's arguments about the moral and psychological aspects of agrarianism, in particular regarding "despair", are original. Its author treats "The Newest Agrarianism", as a source of deconstructive rebellion, hatred, distrust - all that leads to the degradation of both the individual and society, makes it impossible to construct an optimistic model of the future. Instead, agrarianism with its "law of the land", not alluvial, but eternal life values salvation from despair, the basis for building an optimistic perspective ${ }^{21}$. Such thoughts, in our opinion, are reasonable. Agrarianism really seems to be the middle ground between two irreconcilable antagonists: socialism and capitalism. This is the path of development of another, different from the industrial type of society - agrarian one, its culture and philosophy on the basis of the laws of nature, especially the "law of the land". Similar views on the essence of agrarianism were expressed by D. Dragiev, one of the coorganizers and co-founders of the Bulgarian Agrarian National Union. In historiography, he is considered the main theorist of the program of the "third", the peasant, not the capitalist and non-socialist path of social development ${ }^{22}$.

\footnotetext{
18 Липинський В. Листи до братів-хліборобів. Київ ; Філадельфія, 1995. С. 33.

${ }^{19}$ Ibid. C. 32.

${ }^{20}$ Ibid. C. 33.

${ }^{21}$ ЦДАВОВУ, Ф. 4465, Оп. 1, Спр. 747, Арк. 37, Арк. 4.

22 Крапивин А., Бычихин Ю. Аграризм Димитра Драгиева - вождя болгарских крестьян. Вісник Донецького університету, Сер. Б: Гуманітарні наук. 1998. Вип. 2.
} C. $69-70$. 
Developing his judgments about agrarianism, G. Simantsiv gave different versions of the interpretation of this concept: 1) agrarian program; 2) the ideology of agrarian movements; 3) agrarian socio-political system; 4) everything connected with the land, the manifestation of the power of the land over human; 5) unconscious sensual rationalism; 6) scientifically systematized scientific agrarianism - the antithesis of scientific socialism, liberalism, conservatism ${ }^{23}$. In his opinion, "the notion of agrarianism, such as the notion of law, socialism, etc., cannot be defined. Agrarianism can be described, understood and understood, but not defined, even common. This is a whole system of concepts, worldview. Agrarianism has its own fund of ideals, its own social philosophy and its own policy: economic, social, legal, cultural, etc.... The newest agrarianism is the peasant agrarianism ${ }^{24}$. Such an author's approach in the interpretation of agrarianism corresponded to the level of development of that-time agrarianist and socio-political European thought in general. It does not cause fundamental objections in our vision either. At the same time, the thesis that "the concepts of agrarianism... cannot be defined" is debatable.

\section{Socio-economic and philosophical components of agrarianism}

Having presented the author's understanding of modern agrarianism, G. Simantsiv successfully revealed the essence of this phenomenon, the content of its socio-economic, philosophical and other components. In this we see the attempt of the author of "The Newest Agrarianism", to systematize and generalize the previous both European and Ukrainian agrarian intellectual product, to give scientific coherence and integrity to the ideological concept. The social significance of agrarianism, according to the thinker, is that, unlike other socio-political ideologies, he treats the peasantry as "a separate social class of modern society" peasantry, according to the concept of modern agrarianism, is not identical with either the proletariat or the bourgeoisie. The phenomenon of the peasantry is that, unlike the working class, it has "its own middle peasants", and unlike the capitalist, it "lives on the exploitation of its own power, not that of others". The specificity of agricultural production also determined the social peculiarity of the peasantry: "it created from the peasant a kind of middle figure between two extreme, warring forces - the proletarian class

${ }^{23}$ ЦДАВОВУ, Ф. 4465, Оп. 1, Спр. 747, Арк. 37, Арк. 4.

${ }^{24}$ Ibid.

${ }^{25}$ Ibid. Арк. 7. 
and the bourgeoisie class" ${ }^{26}$. In view of this, the peasantry is an independent, separate subject of history, - G. Simantsiv reasonably summarized.

Similar judgments about the essence of agrarianism were expressed by V. Madjara - one of the leaders of tsaranism, who has every reason to understand as a Romanian version of Eastern European agrarianism. For example, he emphasized that tsaranism was a "political movement of the peasant class against the whole system of exploitation and economic domination of capitalist society" ${ }^{27}$. The peasantry, according to the ideology of tsaranism, is a class that "plays a decisive and dominant role in Romanian agrarian society". The Romanian countryside lives its own unique life, which goes beyond both capitalism and socialism ${ }^{28}$.

Agrarianism in the interpretation of the author of "The Newest Agrarianism", understands social stratigraphy in the middle of the peasantry as a natural phenomenon. It is not considered, as with the Bolsheviks, the basis for the aggravation of social contradictions in the peasant environment. It is not the basis for "to see in the peasantry some differentiation of it into several classes with opposite interests" 29 . The theorist of modern agrarianism argued that the integrity of the peasantry, despite the social stratigraphy, is ensured by the commonality of its interests, rather than the degree of economic wealth. Thus, G. Simantsiv understands the peasantry as a community united by common values, interests, etc., as "one family" ${ }^{30}$. The complementary integrity of the peasantry is ensured by the following interests: 1) economic; 2) cultural; 3) political; 4) spiritual; social, etc ${ }^{31}$. According to the author of "The Newest Agrarianism", the range of common interests of the peasantry is wide, it concerns public life in all its diversity.

G. Simantsiv commented on the philosophy of agrarianism no less objectively. He defined it as anthropocentric and peasant-centric. Anthropocentrism is manifested in the following: 1) for agrarianism, each person - first of all a person and a goal in itself, despite the differences in origin, social status, etc.; 2) leaves a person the right of ideological choice: “...it does not call for a fight, neither with religion, nor against it, leaving

${ }^{26}$ ЦДАВОВУ, Ф. 4465, Оп. 1, Спр. 747, Арк. 37, Арк. 7.

${ }^{27}$ Носкова А.Ф. К вопросу об аграризме и крестьянском движении в странах Центральной и Юго-Восточной Европы в межвоенный период. Советское славяноведение. 1981. № 2. С. 52.

${ }^{28}$ Носкова А.Ф. К вопросу об аграризме и крестьянском движении в странах Центральной и Юго-Восточной Европы в межвоенный период. Советское славяноведение. 1981. № 2. С. 52.

${ }^{29}$ ЦДАВОВУ, Ф. 4465, Оп. 1, Спр. 747, Арк. 37, Арк. 8.

${ }^{30}$ Ibid.

${ }^{31}$ Ibid. Арк. 9. 
everyone a free hand to occupy their position in it ${ }^{32}$. Strategically, agrarianism, like other anthropocentric philosophical systems, strives for the universal ideal: "a perfect human in a perfectly organized society"33.

The philosophy of Newest agrarianism, despite the separation of meanings, is closely intertwined with other worldviews, is not detached from pan-European anthropocentric philosophical thought. The peculiarity of its methodology is that universal values are understood from the standpoint of peasant-centrism. G. Simantsiv, like other European agrarianists, believed that the peasantry as an active subject of history is able to create all the necessary conditions for the harmonious intellectual, physical and moral development of the individual ${ }^{34}$.

The ethical principles of agrarianism are based on the fact that it does not overestimate the moral qualities of the peasantry, while not adopting the moral codes of other classes. The ethical principles of the countryside and the moral structure of the countryside are an objective fact, which is perceived by agrarianism as a fact ${ }^{35}$. And in this, in our opinion, its peasantcentrism is clearly manifested.

The starting points in the socio-economic concept of agrarianism are purely sociological issues, - the author of "The Newest Agrarianism", is convinced. Among the important and conceptual, he distinguishes the following: 1) the role and mission of man in society; 2) the dialectic of the relationship between the individual and society, individual social strata; 3 ) "how society should be organized in general and specifically in relation to the interests of the rural people". The answers to these and other questions are based on the fundamental principle of peasant-centrism: "from the point of view of the peasant, his worldview and public interests. The needs of rural life, its imperatives - the main criterion for this" ${ }^{" 36}$.

According to G. Simantsiv, the peasantry played an important social and cultural role in the development of the nation and the state at that time. The author of "The Newest Agrarianism" substantiated his understanding of the role of the peasant as a builder of the state by the historical circumstances of the development of Ukrainians, first of all by the uniqueness of the peasantry in comparison with other national social strata. First of all, he took into account the unique mentality of the Ukrainian peasantry. G. Simantsiv stressed that "in the peasantry, which is closely connected with a certain territory and mentally lives a sense of spontaneous national unity, there are

\footnotetext{
${ }^{32}$ ЦДАВОВУ, Ф. 4465, Оп. 1, Спр. 747, Арк. 37, Арк. 9.

${ }^{33}$ Ibid. Арк. 10.

${ }^{34}$ Ibid. Арк. 11.

${ }^{35}$ Ibid.

${ }^{36}$ Ibid.
} 
solid foundations for stability and endurance of national will in defense of their territory, their land" ${ }^{37}$. Like the classics of European and Ukrainian agrarianism, the thinker spoke of the peasantry as a state builder in view of the following two main, in his opinion, factors: 1) the peasantry is a talisman and embodiment of national values; 2) for the peasantry, the concept and feeling of the Motherland is not an abstraction, but a clear concreteness, nourished by the settlement and practice of management on the native land ${ }^{38}$.

In such judgments of the author of "The Newest Agrarianism", we observe the reflection of Ukrainian agrarianist theory and practice of the early twentieth century, especially the period of the Ukrainian Revolution of 1917-1921. For example, M. Hrushevsky openly believed that, there will be a peasantry, and on it it is necessary to build it. In the long times of our worldly life, we kept repeating that the future of the Ukrainian revival and the future of Ukraine in general lay in the peasantry and only in the peasantry. For a whole century, Ukrainians and peasants became synonymous. Ever since all other strata have betrayed their nationality, all the material for nation-building has been drawn from it, and it has placed its hopes on it: and a force cut from Samson's political and national consciousness. "It (the peasantry - S.K.) became the spring of our revolutionary movement" ${ }^{39}$. S. Efremov, analyzing the ethno-social processes in Ukraine in 1917, considered the peasantry to be the priority layer of state and national construction - the "working masses". He defended the idea that "the basis, the ground for ideological construction among Ukrainians was still the working masses" 40 .

\section{Socio-legal model of agrarianism}

The socio-legal model of agrarianism in G. Simantsiv's interpretation is of scientific interest. The author of "The Newest Agrarianism", revealed its content by applying comparative studies. Following his previous view of agrarianism as the middle ground between capitalism and socialism, he first revealed the socio-legal model of the first two ideological systems, and then clarified the meaning of agrarian. He proposed consideration of the issue from the standpoint of law: the right of the individual and the law of society. According to him, in such a coordinate system, individualism, which is associated with liberalism through political economy, is "the soul of modern

\footnotetext{
${ }^{37}$ ЦДАВОВУ, Ф. 4465, Оп. 1, Спр. 747, Арк. 37, Арк. 11.

${ }^{38}$ Ibid.

39 Грушевський М. Твори : у 50 т. Львів : Світ. 2007. Т. 4. Кн. 1. С. 225-266. C. 252 .

${ }^{40}$ Сфремов С. На партійні теми. Нова Рада. 1917. 9 квітня.
} 
capitalism" ${ }^{\text {41 }}$, which denies society the right to interfere in the relations of individuals and their voluntary associations. Fot the latter it leaves a free hand of action and initiative" ${ }^{, 4}$. Thus, individualism/capitalism/liberalism is the primacy of private law, limiting the role of society. Such a model, according to G. Simantsiv, is an extreme. The antithesis of individualism is collectivism, represented by socialist doctrine. It is another extreme that cultivates the dominance of society in organization and management, regardless of the interest of the individual or even individual social groups.

The author of "The Newest Agrarianism", recognized collectivism as reactionarysm and individualism. He was the first to accuse reactionism, given that he embodies the past historical stage in the development of mankind. The second saw it as a transitional, imperfect model that would soon give way to another - perfect. Given the insignificance of both, agrarianism sees no reason to defend their ideals, and at the same time does not refuse to cooperate with them, as it recognizes them as "those currents that lead to reform and improvement of modernity" 43 .

The optimal socio-legal model, which harmoniously combines private and public relations, according to G. Simantsiv, is agrarianism - "the third logically possible direction", "the middle ground between the above two extreme directions" 44 . According to him, "society has the right and duty to manage and regulate social relations, but so that the initiative of individuals can be freely manifested. Society must not develop to the detriment and cost of killing the individual and his freedom, but equally the individual must not be completely unlimited in its effect to the detriment of society"

Thus, for G. Simantsiv, agrarianism is a balanced social and legal model in which private law correlates with public law. In our opinion, such a model largely corresponds to the categorical imperative of I. Kant: "Act so that the maxims (rules) that govern your will, could become the principles of general law"46.

\section{Agrarianism and the peasant issue}

Modern agrarianism departed from the local and purely class interests of the countryside, the algorithm that was characteristic of tsarist government circles (S. Witte, P. Stolypin), individual governments of the period of

\footnotetext{
${ }^{41}$ ЦДАВОВУ, Ф. 4465, Оп. 1, Спр. 747, Арк. 37, Арк. 12.

${ }^{42}$ Ibid.

${ }^{43}$ Ibid. Арк. 13.

${ }^{44}$ Ibid. Арк. 12.

${ }^{45}$ Ibid.

46 Філософський енциклопедичний словник / В. І. Шинкарук. Київ : Інститут філософії імені Григорія Сковороди НАН України : Абрис, 2002. С. 272.
} 
Ukrainian revolution 1917-1921 (General Secretariat, Council of Ministers). Their understanding was reduced to the consideration of the agrarian/peasant issue as local, economic. To solve it, purely economic tools were proposed to influence the improvement of the socio-economic situation of the peasantry. The latest agrarianism is characterized by a comprehensive approach to its understanding as a set of a number of issues "concerning the economic and cultural existence of the counrtyside in general and its fate in particular" ${ }^{47}$. The theorist believed that the reason lies much deeper - in the imperfection of the socio-political model, a numerical and important component of which is the peasantry. In this way, concludes the logic of his thoughts G. Simantsiv, the solution of the peasant issue - the improvement of social order in general: "These measures must be directed in the direction of improving and reforming all aspects of social relations. Public life is so complex and intertwined that every beat of its pulse in one way or another affects the peasantry, or at least touches it" ${ }^{\prime 8}$. Thus, according to the theorist of the newest agrarianism, the improvement of socio-economic and sociopolitical models in general will lead to the improvement of all aspects of peasant life. Given the numerical dominance of the peasantry in Central and Eastern European, especially Ukrainian, societies, the peasantry is an active subject of constructive transformations. This is due to its unique role in state- and nation-building.

Denying the importance of class antagonism, dictatorship, revolution as the locomotives of history, not accepting their meanings, agrarians proposed an alternative tool for improving society, in particular in the socio-economic and socio-political spheres. The main goal in the evolution of the social model, in accordance with the provisions of modern agrarianism, is "people and their good. This goal is common, and should be common to all sections of society" 49 . It can be achieved through the cooperation of "all social strata and units and their associations"50. Cooperation with G. Simantsiv was widely interpreted. In it he puts the following meanings: 1) "instead of class struggle - class cooperation"; 2) "instead of social struggles - mutual compromises and concessions for the common good"; 3 ) "cooperation of all living forces of the people"; 4) the harmonious development of "all components of society, and hence the individual" ${ }^{15}$. In fact, the author of "The Newest Agrarianism", in our opinion, proposed an innovative for its time understanding of cooperation as a tool for implementing

\footnotetext{
${ }^{47}$ ЦДАВОВУ, Ф. 4465, Оп. 1, Спр. 747, Арк. 37, Арк. 15.

${ }^{48}$ Ibid.

${ }^{49}$ Ibid. Арк. 16.

${ }^{50}$ Ibid.

${ }^{51}$ Ibid. Арк. 17.
} 
complementary socio-economic and socio-political models. Complementary society - a society of common values and ideals, development, prospects, comfort, harmonious combination of individual and collective principles.

The modern agrarianism saw the solution of such a component of the peasant issue as agrarian / land on the principles different from the previous ones. First of all, he understands it as a component of a holistic agrarian policy to solve the peasant question in general; secondly, its solution will take place on the basis of economic and legal programs of agrarianism, which provides for the existence of such an institution as the institution of private property $^{52}$; third, it is a peaceful solution based on expediency and possible justice ${ }^{53}$. As an option, G. Simantsiv is reasonably relevant the use of such a tool as parcelling. In his favor, he puts forward the following arguments: 1) this is true, because the peasantry will receive land that previously belonged to them and which was alienated from them; 2) it is expedient, as it is a guarantee of preservation of social peace and "preservation of folk culture" 54 . The peasantry must clearly benefit from the solution of the agrarian/land issue: "The land must belong to the peasant legally and in fact. There is no peasantry without land and without land. And that's why there can be no problems here" ${ }^{, 55}$. In our opinion, such an idea of modern agrarianism was conditioned by the experience of the revolutionary struggle of the Ukrainian peasantry in 1917-1921, by peasant ideology. At the heart of this ideology of the peasantry during the Ukrainian Revolution was the original desire for "land and freedom". These two concepts were closely intertwined in the minds of the peasants and had a sacred meaning for them. In this way we can state that the peasants understood and perceived all the complexity of socio-political relations, relations with the authorities through the prism of agrarian-natural existence $^{56}$.

Prospects for the economic development of the peasantry by agrarianism were not identified with the development of large landholdings. G. Simantsiv noted that agrarianism is the antithesis of latifundism. His position is in solidarity with the Hetman's 1918. On the future of Ukraine, the Ukrainian peasantry and agriculture, P. Skoropadsky wrote: "I am a supporter of small farms, particularly in Ukraine, and has repeatedly said

${ }^{52}$ ЦДАВОВУ, Ф. 4465, Оп. 1, Спр. 747, Арк. 37, Арк. 17.

53 Ibid.

${ }^{54}$ Ibid.

55 Ibid. Арк. 29.

56 Михайлюк О. Щодо «політичної програми» селянства України в період революції та громадянської війни. Украӥнський селянин. 2003. № 7. С. 103-106. 
that my ideal is to see Ukraine covered only by small highly productive, private households..."57.

The solution of the agrarian/land issue on the basis of latifundism is unacceptable for agrarianism ${ }^{58}$. The option of solving the agrarian/land issue from the standpoint of black redistribution is ineffective for agrarianism. Under the conditions of that time, as under modern ones, land without capital is simply a natural resource that is not a market category. Land capitalization is no less important for peasants than land ownership. Guided by the "middle" way, modern agrarianism at the same time in the category of "capital" did not exhaust the complexity of all that "determines the welfare of the peasant" 59 . The combination of land and capital does not guarantee that the peasantry will receive the remuneration due to him for his work. Such a guarantor, according to the theorist of modern agrarianism, is the profitability of agriculture in general. It determines the fair wage of the peasant, not the size of land tenure / land use. In this way, the triad: land capital - profitability - the formula for the formation of the wealthy peasantry - the socio-cultural basis of the nation and state.

We are impressed by such theoretical approaches of modern agrarianism to the solution of the agrarian issue. To a large extent, their origins originate in the program provisions of the agrarianist political parties of the period of the Ukrainian Revolution of 1917-1921, as well as certain agrarianist practices of that time in solving the agrarian question. For example, the political program of the Ukrainian Democratic Agrarian Party, the agrarian policy of the Hetmanate of 1918. In view of this, there is reason to talk about the longevity of the Ukrainian agrarian tradition in theoretical developments and practical measures.

\section{Agrarianist state-building}

A special place in the theory of modern agrarianism is given to the state, the dialectic of individual-society-state relations, the principles of state building, and so on. The image of the agrarianist state is to a large extent a logical continuation of the previous principles of modern agrarianism. He avoided the absolutization/glorification of the state, as he avoids its denial, ie extremes in its interpretation. For him, the state is a form of "organization of society in the current state of human culture and civilization" ${ }^{\natural 0}$. In other words - the result of the natural evolution of society,

\footnotetext{
${ }^{57}$ Скоропадський П. Спогади. Київ ; Філадельфія, 1995. С. 137.

${ }^{58}$ ЦДАВОВУ, Ф. 4465, Оп. 1, Спр. 747, Арк. 37, Арк. 29.

${ }^{59}$ Ibid. Арк. 30.

${ }^{60}$ Ibid. Арк. 19.
} 
nation, objective phenomenon. Accordingly, the understanding of its essence is different from other ideologies, such as Marxism. G. Simantsiv understands it as a state for society, as a means, not as an instrument of violence of those in power to retain power. In his opinion, the best is the form of the state, "which most certainly provides the conditions under which every citizen would be able to fully and comprehensively show their strength and materially ensure their existence" ${ }^{\text {"61 }}$.

Democracy is a fundamental principle of the agrarian state. It reflects its fundamental essence, purpose - "the good of all citizens" ${ }^{2}$. Such a state model, based on civil society, ensures "all adult citizens, regardless of status, family and property, complicity in the creation of state will"63. This complicity was realized by Ukrainian peasants during the peasant republicbuilding of the period of the Ukrainian Revolution of 1917-1921. As a sociocultural, integral historical phenomenon, the peasant republic was the result of the peasant revolution, a manifestation of peasant revolutionism, peasant revolt ${ }^{64}$, realization of the political program of the peasantry, a form of socio-political and social self-organization of the peasantry, the embodiment of common peasant values and ideals. It convincingly testified to the appearance in the historical arena of that time of a new active subject of history - the peasant. The source of power in these formations were the peasantry, power was formed on an electoral democratic basis ${ }^{65}$.

In the complementary unity is the power of such a state. This is the fundamental difference between the agrarianist state and the class state. The latter delegates all power to one class to the detriment of the interests of other classes, - G. Simantsiv argued ${ }^{66}$. In accordance with this interpretation of the agrarian state, the concept of the model of its basis has been developed. It is fundamentally different from liberalism and collectivism. The latter are rejected by the latest agrarianism as one-sided, given the dominant in the first case of individual, in the second - collective. Taking this into account, the optimal for theorists of modern agrarianism is another "economic organizational principle", which is due to the objectives of the

${ }^{61}$ ЦДАВОВУ, Ф. 4465, Оп. 1, Спр. 747, Арк. 37, Арк. 20.

${ }^{62}$ Ibid.

63 Ibid.

${ }^{64}$ Корновенко С. Суб'єктний складник аграрного питання як одна 3 передумов Української революції 1917-1921 рр. Украӥнський історичний журнал. 2017. № 4. C. 83-94.

65 Корновенко С., Берестовий А., Компанієць О., Пасічна Ю., П'янзін С., Щербаков М. Селянське республікотворення періоду Української революції 1917-1921 рр. Черкаси : Чабаненко Ю.А., 2019. 220 с.

${ }^{66}$ ЦДАВОВУ, Ф. 4465, Оп. 1, Спр. 747, Арк. 37, Арк. 20. 
national economy. It is also determined by the ideal of "human and people, a people healthy, morally strong and educated, and at the same time a democratic people, all components of which are equal and where any supremacy of one or another stratum would be excluded"67. The guarantor of the realistic existence of such an ideal is the material security of people, their existence. Given this, farmers argue that the proper material security of man and society - the leading idea of economic policy, the main economic task ${ }^{68}$.

G. Simantsiv successfully polemized with the liberal school of political economy. He opposed the thesis of the liberal school of political economy that the highest productivity of economic goods, the cheapest supply of consumers - a priority of the economic complex. He substantiated other principles of agrarian political economy. According to them, the main thing is not so much the volume of production as their fair distribution "between individual economic entities". Thus, the goal of the agrarianist model of the national economic complex is the profitability of "economic activity of an individual, still independently, at their own risk, working or working for hire" 69 , not only the production of material goods, but also their fair distribution.

The source of profitability is labour, its results. At the same time, the labour of the peasant, as well as the employee, is "threatened"70. The latest agrarianism under such conditions is, among other things, the system of labour protection in the countryside. The concept of "labour protection" is interpreted as measures of the agrarianist state, aimed at "providing the peasant with appropriate measures of agricultural policy, this profitability and supply..."71. The ultimate goal of such "labour protection" is an economically strong peasant - grain-grower, a successful state in general.

The agrarianist economic programme is a way of systematic, in accordance with the laws of evolution, restructuring of the social order on the basis of institutional complementarity - the original model of complementarity of economic institutions. Modern Japan, for example, is developing according to this model. This, in our opinion, is its difference from the then revolutionary socialism, liberalism, conservatism. In this context, G. Simantsiv wrote about economic and political cooperation of all social strata of society and the state. It is the responsibility of the latter to create the appropriate conditions under which the business entity can reach

\footnotetext{
${ }^{67}$ ЦДАВОВУ, Ф. 4465, Оп. 1, Спр. 747, Арк. 37, Арк. 20.

${ }^{68}$ Ibid.

${ }^{69}$ Ibid. Арк. 21.

${ }^{70}$ Ibid.

${ }^{71}$ Ibid. Арк. 22.
} 
its full potential, "but without harming or exploiting others"72. A similar position was defended by Bulgarian agrarianists. For example, D. Dragiev also considered cooperation to be the optimal form of land management. $\mathrm{He}$ saw the main task of the government in the agricultural sector not to radically eliminate the already existing agrarian relations, but to provide conditions for the gradual growth of the welfare of the peasantry on the basis of cooperation ${ }^{73}$.

The legal program of agrarianism is based on the principle of private property right ${ }^{74}$. In this context, in our opinion, it fully reflects the national agrarianist tradition, in particular the period of the Ukrainian Revolution of 1917-1921, presented in the "Letter to the whole Ukrainian people" of April 29, 1918. The Hetman's document stated that the right of private property - the foundation of culture and civilization ${ }^{75}$. Substantiating this approach, the author of "The Newest Agrarianism", reasonably stated: 1) only private property best provides a person with justice in the results of his work; 2) private property - the most powerful motivator of man "to economic activity, diligence, creativity and entrepreneurship"; 3) historical experience, in particular Ukrainian, convinces, "that only they who owns and has power, who owns the land, this basis of life"76.

According to the concept of the newest agrarianism as a "middle way", private property is not only a right, it is also a duty. First of all, "to own means not only to have the right to dispose of this object indefinitely, possibly to manage it in such a way that it benefits not only the owner, but also the whole society" ${ }^{\text {,7 }}$. In this way, legal agrarianism is qualitatively different from capitalism and socialism. It does not accept the anti-cultural and anti-social tendencies of capitalism and denies the socialist ideology of abolishing the institution of private property, which is understood as a source of "human poverty"78.

Managing with the thesis that the meaning of human life lies in the possibility of improvement, the concept of modern agrarianism provides for an appropriate agrarianist social policy. In its content it is anthropo- and

72 ЦДАВОВУ, Ф. 4465, Оп. 1, Спр. 747, Арк. 37, Арк. 23.

${ }^{73}$ Крапивин А., Бычихин Ю. Аграризм Димитра Драгиева - вождя болгарских крестьян. Вісник Донецького університету, Сер. Б: Гуманітарні наук. 1998. Вип. 2. C. 71 .

${ }_{75}^{74}$ ЦДАВОВУ, Ф. 4465, Оп. 1, Спр. 747, Арк. 37, Арк. 24.

75 Аграрне законодавство періоду Української революції (1917-1921рp.): збірник документів і матеріалів / упоряд.: С.В. Корновенко, А.Г. Морозов, Ю.Г. Пасічна. Черкаси : Чабаненко Ю.А., 2019. С. 96.

${ }^{76}$ ЦДАВОВУ, Ф. 4465, Оп. 1, Спр. 747, Арк. 37, Арк. 25.

${ }^{77}$ Ibid.

${ }^{78}$ Ibid. 
peasant-centric. Its task is to prevent natural disasters (hunger, cold, disease, mutilation, etc.) and to protect society from degradation or to mitigate the effects of such social deviations as moral depravity, crime, etc. Agrarianist social program is a socially complementary project. Its implementation is aimed at all segments of society, to eliminate class conflicts, to prevent natural, demographic, social cataclysms. The tool in the implementation of agricultural social policy are the relevant social institutions that are subordinated to the ideas of "socially healthy countryside and city"79.

Like other components of modern agrarianism, the cultural agrarianist program is an integral part of a holistic agrarianist approach to the evolutionary and natural improvement of society, the solution of the peasant issue in general. Without the cultural development of the countryside, agrarianists could not imagine an economic, political, social, etc. solution to the peasant issue ${ }^{80}$. G. Simantsiv understood culture as an important factor in the "progress of the countryside as a whole" political liberation of the Ukrainian peasantry from serfdom made him an equal member of society are correct, but "this did not make the peasant free; he is still far from true freedom, he is still burdened by the stern of spiritual darkness, superstitions, humiliation, unfounded fear of the "powerful" and all the other remnants of the old, feudal-serfdom times" $" 82$. On the basis of such an understanding of the situation in the cultural life of the peasantry with the latest agrarianism and formulated the task of agrarian cultural policy, designed to "bring a ray of light into this darkness, free the peasant from spiritual backwardness, make science and art available to him, beautify his life with cultural interests" $"$.

In this approach to cultural policy towards the peasantry, proposed by the latest agrarianism, we observe the longevity of traditions in Ukrainian agrarian thought. For example, P. Kulish's reasoning in the hamlet philosophy was similar to the above. The uniqueness of peasant education, according to the thinker, is that it forms a harmonious personality that is intellectually developed, spiritually rich, with an non-lost identity. P. Kulish was in favor of the peasants reading, knowing, and being interested in what was "going on in the world". He was convinced that "if you do not know the world of God widely, you will not know what is worthwhile" ${ }^{\text {}}$.

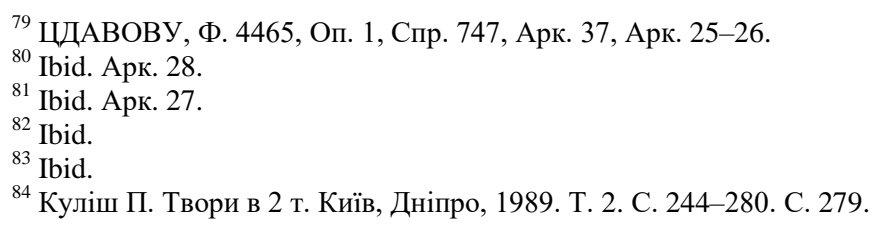




\section{The main features of agrarianism}

Summarizing the essence of the newest agrarianism, G. Simantsiv identified the main, in his opinion, features/characteristics. First of all, the newest agrarianism is a new socio-political system, a holistic realistic worldview. Its appearance is due to "real objective circumstances and it understands this life and tries to influence it only on the basis of modern social relations and the means of veche abilities. Realism in ideas, realism in ranks" ${ }^{\prime \prime 5}$. At the same time, agrarianism is the middle ground between collectivism and individualism. Its purpose is to create "the most favorable conditions for the peasantry for its existence and development" ${ }^{\prime \prime 6}$. Thus, agrarianism is a peasant-centric phenomenon.

The second. A characteristic feature of the newest agrarianism is its historicism in the form of elasticity. It is not dogmatic, despite the fact that G. Simantsiv positioned it as a "peasant political religion" 87 . The newest agrarianism is gaining the meaning "given to it by the peasantry itself". This does not deny that agrarianism is a holistic and natural phenomenon, because "the peasant worldview and psychology are generally common to all peoples and at all times. The laws of nature apply here, under which the peasantry and their own lands work over man, which are the same and unchanging in every country" $" 88$.

The third. One of the foundations of the latest agrarianism is its democracy. This is due to the fact that the nature of the peasantry is actually democratic. Democracy, according to the theorist of modern agrarianism, is an instrument of internal social complementarity. The latter is "the only reliable guarantee of social peace" ${ }^{\$ 9}$.

The fourth. The latest agrarianism systematically and consistently defends the understanding of the peasantry as a separate subject of history, as a "separate social class". The peasantry is radically different from the proletariat and the bourgeoisie, it is a separate, "new social type - the agrarian" $"$. Separation primarily lies in the syntheticity of the peasantry, "because it carries the beginnings of collectivism and individualism", it is all labour ${ }^{91}$.

\footnotetext{
${ }^{85}$ ЦДАВОВУ, Ф. 4465, Оп. 1, Спр. 747, Арк. 37, Арк. 32.

${ }^{86}$ Ibid.

${ }^{87}$ Ibid. Арк. 33.

${ }^{88}$ Ibid.

${ }^{89}$ Ibid. Арк. 34.

${ }^{90}$ Ibid. Арк. 33.

${ }^{91}$ Ibid. Арк. 33-34.
} 
The fifth. The newest agrarianism is focused on the social protection of those "whose labour consequences are threatened" $"$. Social protection tools for different categories of society are different, taking into account the characteristics of social strata. They are special for the peasantry. Social protection of the peasantry by agrarianism is interpreted broadly - the social protection of the peasantry, the preservation of its political, professional, cultural and social institutions ${ }^{93}$.

The sixth. Agrarianism contrasts the modern city with the modern countryside. According to G. Simantsiv, these two worlds are mutually interested in each other. The countryside fed the city biologically. The newest agrarianism calls for the countryside to nourish the city also ideologically. In this, agrarianism sees the task of the peasantry - "to restore this balance and balance the extremes of modern society. The peasantry must bring to the modern city the primordial human goods lost by this city nature and peace" $"$.

The seventh. Agrarianism does not exaggerate the role and importance of innovations, rapid and unexpected social transformations. It is careful about this, guided by psychological and material motives: do not rush and do not procrastinate. "New ideas must first of all mature well in the minds and souls of the people" 95 . Only after that it is necessary to implement them in practice. Priority should be given to the work and efforts aimed at the accumulation of national wealth, "appropriate management and fair distribution of the results of the national economy among members of the nation" $"$.

\section{CONCLUSIONS}

Thus, summarizing, we state. G. Simantsiv's speech "The Newest Agrarianism" is a Ukrainian intellectual product related to such a peasantcentric phenomenon of the second half of the nineteenth century - 1930s as agrarianism. The report outlines the Ukrainian version of agrarianism as a socio-political ideology. Conceptually, the Simantsiv model of modern agrarianism is based on understanding not only European agrarianist theoretical thought, but also Ukrainian. The longevity of the Ukrainian intellectual agrarianist tradition, which is presented in the report, is obvious. G. Simantsiv managed to logically and consistently reveal the essence and content of modern agrarianism. He substantiates the principles and positions

\footnotetext{
92 ЦДАВОВУ, Ф. 4465, Оп. 1, Спр. 747, Арк. 37, Арк. 34.

${ }^{93}$ Ibid. Арк. 34-35.

${ }^{94}$ Ibid. Арк. 35.

${ }^{95}$ Ibid.

${ }^{96}$ Ibid.
} 
of modern agrarianism, relating to the individuality of the peasantry, its mentality, the role of the peasantry as an active subject of state- and nationbuilding, and so on. In our opinion, the intellectual heritage of G. Simantsiv, presented in the report "The Newest Agrarianism", is a generalization of European and Ukrainian agrarianist theoretical thought, a coherent and wellfounded Ukrainian concept of agrarianism of that time.

\section{REFERENCES}

1. Аграрне законодавство періоду Української революції (1917-1921 pp.) : збірник документів і матеріалів / упоряд.: С.В. Корновенко, А.Г. Морозов, Ю.Г. Пасічна. Черкаси : Чабаненко Ю.А., 2019. 554 с.

2. Грушевський М. Твори: у 50 т. Львів : Світ. 2007. Т. 4. Кн. 1. $407 \mathrm{c}$.

3. Давидюк Р. Українська політична еміграція в Польщі: склад, структура, громадсько-політичні практики на території Волинського воєводства: дис. ... док. іст. н. Львів, 2017. 704 с.

4. Даниленко О. Українська еміграція в Чехословаччині. URL: https:// etnic.history.univ.kiev.ua/data/2001/10/articles/6.pdfx.

5. Єфремов С. На партійні теми. Нова Рада. 1917. 9 квітня.

6. Корновенко С. Суб'єктний складник аграрного питання як одна 3 передумов Української революції 1917-1921 pp. Украӥнський історичний журнал. 2017. № 4. С. 83-94.

7. Корновенко С., Берестовий А., Компанієць О., Пасічна Ю., П'янзін С., Щербаков М. Селянське республікотворення періоду Української революції 1917-1921рр. Черкаси : Чабаненко Ю.А., 2019. $220 \mathrm{c}$.

8. Крапивин А., Бычихин Ю. Аграризм Димитра Драгиева - вождя болгарских крестьян. Вісник Донеиького університету, Сер. Б: Гуманітарні наук. 1998. Вип. 2. С. 69-72.

9. Куліш П. Твори в 2 т. Київ : Дніпро, 1989. Т. 2. 354 с.

10. Ленин В. Полное собрание сочинений. Москва, 1976. Т. 16.

11. Ленин В. Полное собрание сочинений. Москва, 1979. Т. 12.

12. Липинський В. Листи до братів-хліборобів. Київ, Філадельфія, 1995. $470 \mathrm{c}$.

13. Михайлюк О. Щодо «політичної програми» селянства України в період революції та громадянської війни. Український селянин. 2003. № 7. C. 103-106.

14. Носкова А.Ф. К вопросу об аграризме и крестьянском движении в странах Центральной и Юго-Восточной Европы в межвоенный период. Советское славяноведение. 1981. № 2. С. 40-57. 
15. Пеленська О. Україна поза Україною: Енциклопедичний словник мистецького, культурного i громадського життя в міжвоєнній Чехословаччині (1919-1939). Прага, 2019. 331 с.

16. Плазова Т. Діяльність української еміграції в країнах Європи у міжвоєнний період XX ст. URL: https://ena.lp.edu.ua.

17. Плазова Т. Українська еміграція в країнах Європи в міжвоєнний період ХХ ст. Науковий вісник ЛНУВМБТ імені С.Г. Гжицького. 2010. Т. 12. № 2 (44). Ч. 5. С. 225-229.

18. Плазова Т. Українська політична еміграція у першій половині 20-х років ХХ ст. Українська національна ідея: реалії та перспективи розвитку. 2008. Вип. 20. С. 118-121.

19. Сафонов Д. Крестьянство как объект и субъект процесса модернизации. Вісник Черкаського університету. Серія: Історичні науки. 2012. № 35 (248). С. 15-18.

20. Скоропадський П. Спогади. Київ, Філадельфія, 1995. 493 с.

21. Уткін О. Вища аграрна школа української еміграції (1922-1935 рр.). Київські історичні студї. 2018. № 1 (6). С. 94-102.

22. Філософський енциклопедичний словник / B.I. Шинкарук. Київ : Інститут філософії імені Григорія Сковороди НАН України : Абрис, 2002. 742 с.

23. Центральний державний архів вищих органів влади і управління України, Ф. 4465, Оп. 1, Спр. 747. 